\title{
Recent advances in understanding the role of metabolic heterogeneities in cell migration
}

\author{
Jenna A Mosier $^{1 \mathrm{X}} \quad$ Yusheng Wu ${ }^{1 \mathrm{x}} \quad$ Cynthia A Reinhart-King ${ }^{1 *}$ \\ ${ }^{1}$ Department of Biomedical Engineering, Vanderbilt University, Nashville, TN, USA \\ ${ }^{\mathrm{x}}$ Equal contributors
}

\begin{abstract}
Migration is an energy-intensive, multi-step process involving cell adhesion, protrusion, and detachment. Each of these steps require cells to generate and consume energy, regulating their morphological changes and force generation. Given the need for energy to move, cellular metabolism has emerged as a critical regulator of both single cell and collective migration. Recently, metabolic heterogeneity has been highlighted as a potential determinant of collective cell behavior, as individual cells may play distinct roles in collective migration. Several tools and techniques have been developed and adapted to study cellular energetics during migration including live-cell probes to characterize energy utilization and metabolic state and methodologies to sort cells based on their metabolic profile. Here, we review the recent advances in techniques, parsing the metabolic heterogeneities inherent in cell populations and their contributions to cell migration.
\end{abstract}

\section{Keywords}

cancer, collective migration, ATP, heterogeneity, metabolism, extracellular matrix

\section{Peer Review}

The peer reviewers who approve this article are:

1. Alan Howe, Department of Pharmacology, University of Vermont Larner College of Medicine, University of Vermont Cancer Center, Burlington, VT, USA

Competing interests: No competing interests were disclosed.

2. Alexis Gautreau, CNRS UMR7654, Ecole Polytechnique, Institut Polytechnique de Paris, Palaiseau, France Competing interests: No competing interests were disclosed. 
*Corresponding author: Cynthia A Reinhart-King (cynthia.reinhart-king@vanderbilt.edu)

Competing interests: The authors declare that they have no competing interests.

Grant information: This work was supported by the National Institute of Health (GM131178) and the National Science Foundation Graduate Fellowship (DGE-1937963) to J.A.M.

The funders had no role in study design, data collection and analysis, decision to publish, or preparation of the manuscript.

Copyright: (C) 2021 Reinhart-King CA et al. This is an open access article distributed under the terms of the Creative Commons Attribution License, which permits unrestricted use, distribution, and reproductison in any medium, provided the original work is properly cited.

How to cite this article: Mosier JA, Wu Y and Reinhart-King CA. Recent advances in understanding the role of metabolic heterogeneities in cell migration. Faculty Reviews 2021 10:(8) https://doi.org/10.12703/r/10-8

Published: 28 Jan 2021, Faculty Reviews 10:(8) https://doi.org/10.12703/r/10-8 


\section{Introduction}

Cellular bioenergetics play a significant role in many essential biological processes including growth and proliferation, allowing cells to adapt to a changing environment ${ }^{1}$. Cellular energy utilization and metabolic plasticity can improve cell fitness and regulate disease progression by maximizing energy production and providing the necessary intermediates for biosynthetic processes ${ }^{2-7}$. However, it has only recently been reported that cell metabolism may play an important role in migration $^{8,9}$, with intracellular energy generation still being explored.

Recent evidence suggests that cells have distinct energetic needs depending on their mode of migration ${ }^{3}$. Cells can move both as individual cells and as collective cohorts, adopting a variety of migratory modes, ranging from Rac1-dependent mesenchymal $^{10-13}$ to RhoA-mediated amoeboid migration ${ }^{14-16}$. In addition to plasticly switching between these migratory modes or adopting intermediate characteristics of each ${ }^{11,16-21}$, migratory cells are also able to switch between two main metabolic pathways: glycolysis or oxidative phosphorylation $(\mathrm{OXPHOS})^{22}$. Energy requirements depend on cell morphology, physical properties of surrounding environments, and cell-environment interactions and are therefore determining factors in cell migration ${ }^{3}$.

Collective migration is characteristic of a number of biological processes, including development, wound healing, and invasive diseases like cancer, where energy utilization and efficiency have recently been shown to play a significant role ${ }^{23-26}$. It has been reported that both single and collective cell migration may demand that certain energetic requirements be met during migration ${ }^{9,27-30}$. In single cells, the more energy-efficient, mitochondrial ATP generation occurs at the leading edge of cells ${ }^{8}$, whereas during collective migration, there is no consensus in the current literature on energy production at the leading edge of the cell front compared to the central follower cells ${ }^{31,32}$. Cell metabolic pathways and energy sources are of key interest in the context of cancer, as a better understanding of these processes could provide efficient targets for treating cancer and inhibiting cell invasion. Therefore, newly developed tools and techniques available for studying cell metabolism during migration have enabled further investigation of cellular energetic needs and the mechanisms by which energy is generated.

\section{Molecular probes for studying cell metabolism during migration}

Cell metabolism has primarily been characterized using bulk techniques analyzing metabolic genes and proteins and with tools such as the Seahorse Analyzer XF that reports oxygen consumption and extracellular acidification rates of cell populations ${ }^{33-36}$. However, as more is learned on the heterogeneity of cell populations and migratory ability, it becomes clear that understanding individual cell energetics can shed light on these complex and intricate processes. Molecular probes that can be stably expressed in multiple cell lines are able to map these minute changes on a cell-by-cell basis to study single cell energetics in the context of larger cell populations. Many fluorescent biosensors thus exist to interrogate cell metabolism in real time, including those measuring the metabolic intermediates lactate ${ }^{37}$ and pyruvate ${ }^{38}$ or mitochondrial membrane potential $^{39}$. Here, we have focused on just a few of the many probes used to investigate cell migration and metabolism.

\section{PercevalHR probe: visualizing ATP:ADP ratios}

Adenosine triphosphate (ATP) and adenosine diphosphate (ADP) are two key components of energy transfer in cells, with ATP being essential in multiple migratory mechanisms including actomyosin contractility ${ }^{40}$, actin polymerization ${ }^{41}$, and cytoskeletal remodeling ${ }^{42,43}$. ATP:ADP ratios are useful in reporting the availability of these metabolic intermediates. The PercevalHR probe boasts the ability to track real-time ATP:ADP ratios and localization as cells migrate, providing substantial insight about the relationship between cell energy utilization and migration in various cell microenvironments ${ }^{44}$. PercevalHR combines a fluorescent protein with the bacterial regulatory protein GlnK1 that competitively binds to active ATP and $\mathrm{ADP}^{44,45}$. The probe has two distinct excitation wavelengths for ATP and ADP binding and has been successfully used to measure a ratio of these values in yeast cells ${ }^{46}$, HeLa cells ${ }^{47}$, pancreatic beta cells ${ }^{48,49}$, neuronal cells $^{50}$, fibroblasts ${ }^{51}$, metastatic breast cancer cells $\mathrm{s}^{9,30}$, and many others to report cell energy status.

By quantifying ATP:ADP in individual live cells, it is possible to probe the role of cell metabolism in migration. The Warburg effect postulates that glycolysis is preferred over mitochondrial respiration in energy production ${ }^{52}$, generating interest in how this altered energy dynamic regulates migration and interaction with the extracellular matrix $(\mathrm{ECM})^{53}$. In dense, more-challenging environments, ATP:ADP ratios in cancer cells are elevated, likely to meet the higher energetic demands of cells navigating the $\mathrm{ECM}^{9}$ (Figure 1A). When presented with fewer impediments in aligned matrices, that ratio significantly drops, suggesting that cells can specifically tune energy levels to meet the demands of the surrounding matrix architecture. Additionally, PercevalHR has been utilized to explore the relationship between confinement and bioenergetics during migration, where increased confinement typically imposes a higher energetic demand on cells ${ }^{30}$ (Figure 1B-E). Moreover, cells tend to follow the path of least resistance in these energy requirements, as cells preferentially migrate into less confined, potentially less energy-intensive pathways. The ability to monitor ATP:ADP levels in single cells and correlate those with migration metrics like velocity has been a powerful tool in demonstrating that cells adapt energy levels based on their migration behavior and microenvironment.

In addition to modulating ATP:ADP levels during migration, cells exhibit changes in energy localization in response to mitochondrial positioning that can significantly affect migratory ability $^{51}$. Recent data suggest that intracellular energy distribution, mapped using PercevalHR, modulates migration and controls features such as protrusive and adhesive activity and, consequently, migration speed in embryonic fibroblasts. When 


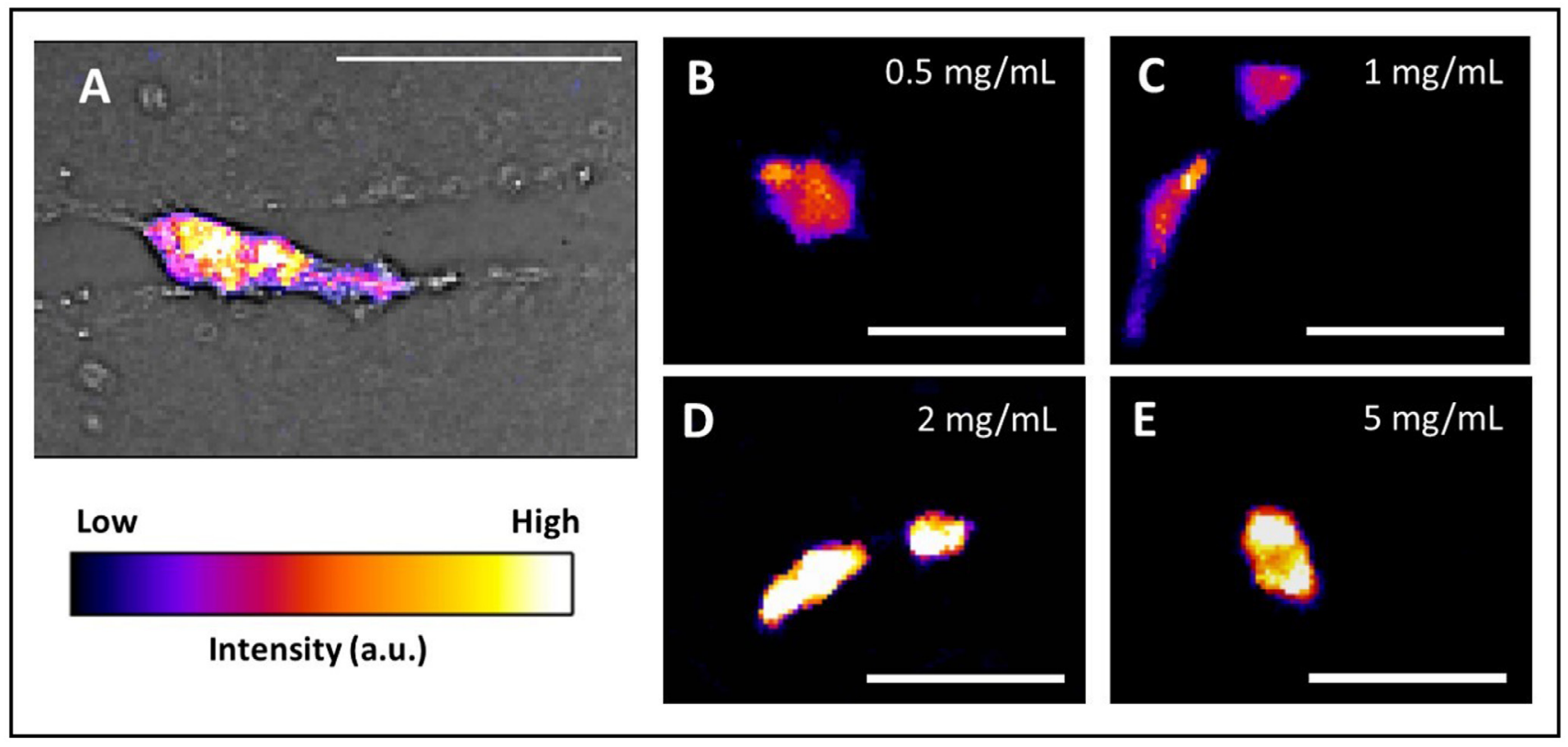

Figure 1. The PercevalHR probe can be used to image ATP:ADP ratios in various microenvironments. (A) Heat map of PercevalHR/ pHRed probe in MDA-MB-231 cell migrating in a microfabricated collagen microtrack (scale bar $=50 \mu m$ ). (B-E) Heat map of PercevalHR/ pHRed probe in MDA-MB-231 cells in 3D collagen densities of B) $0.5 \mathrm{mg} / \mathrm{mL}, \mathbf{C}) 1 \mathrm{mg} / \mathrm{mL}, \mathbf{D}) 2 \mathrm{mg} / \mathrm{mL}$, and E) $5 \mathrm{mg} / \mathrm{mL}(\mathrm{scale}$ bar $=50 \mu \mathrm{m})$.

ATP:ADP ratios are reduced at the cell periphery and mitochondria become restricted to the perinuclear space, decreased membrane dynamics and adhesion stability mediated by the Rho-GTPase Miro-1 attenuate migration in both single and collective cells. Evidence suggests that Miro-1 is required for migration and wound healing during injury of epithelial cells $\mathrm{s}^{54}$, highlighting the importance of mitochondrial function in mediating cell migration.

PercevalHR has proven a useful, viable tool not only in vitro but also ex vivo ${ }^{50}$. PercevalHR-transduced cells were injected into the subventricular zone of adult mice, and brain tissue sections were removed and time-lapse imaged. Cells actively and dynamically changed ATP:ADP ratios, promoting autophagy to regulate the pace of migratory and stationary phases in the cell. This work lays the foundation for both further use of probes in highly relevant, ex vivo and in vivo environments as well as understanding how energy consumption is essential in key migratory processes. Since so few techniques for investigating cell migration are applicable to in vivo studies, molecular probes hold the potential to further elucidate more relevant and useful therapeutic targets for many aggressive diseases.

\section{Visualizing NADH:NAD+ redox state}

The cytosolic NADH:NAD+ redox state is an important indicator of bioenergetics that drives the flow of electrons during the electron transport chain. Nicotinamide adenine dinucleotide (NAD) reduces to NADH when it accepts an electron, and both are essential cofactors in glycolysis, the citric acid cycle, and OXPHOS ${ }^{55}$. The ratiometric Peredox probe reports NADH:NAD+ ratios in live cells by incorporating the bacterial redox-sensing, transcriptional repressor Rex that competitively binds $\mathrm{NADH}$ and NAD+ and increases fluorescence upon binding to $\mathrm{NADH}^{56,57}$. In addition to correlating the redox state with glycolysis in bacterial cells $\mathrm{s}^{58,59}$, neural cells ${ }^{60}$, neuroblastoma and epithelial cells ${ }^{56}$, and melanoma cells ${ }^{61}$, Peredox has been used to elucidate the role of key glycolytic and OXPHOS mediators in cancer cell invasion ${ }^{61}$.

Recently, Peredox was used to interrogate the role of Citrin, the mitochondrial transporter, in increasing cancer cell invasion by measuring the relative levels of NAD+ and $\mathrm{NADH}$ during energy production in cells where the transporter was silenced ${ }^{61}$. While NAD+ and NADH levels were both found to decrease in cells lacking Citrin, levels of glycolysis and OXPHOS similarly decreased, suggesting that Citrin aids in providing intermediates for both energetic pathways. However, Peredox is not the only probe that takes advantage of the competitive binding of Rex. Similar variations of the construct have been used to highlight glycolysis as a determinant of cell migration in development. A Rex probe paired with yellow fluorescent protein reported that neural crest migration depends heavily on glycolysis and is abrogated in cells utilizing OXPHOS $^{62}$. This has been echoed in recent studies, where increased glycolysis and its intermediates were linked to increased migration ${ }^{29,63-68}$. These probes allow visualization of the inherent metabolic plasticity of cells and how migratory phenotypes are altered when cells utilize different energy pathways. 


\section{2-NBDG probe: visualizing glucose uptake}

Glucose fuels glycolysis, releasing ATP and other factors that feed into OXPHOS. 2-NBDG is a modified, fluorescent glucose analog that is effectively taken up by cells, but not utilized during glycolysis, and thus serves to report glucose uptake in cells $^{69}$. This probe has been used as an indicator of glycolysis to study cancer cell migration in particular, as cancer cells are known to exhibit increased glucose uptake and glycolysis to support increased proliferation. Increased 2-NBDG fluorescence has been correlated with increased migration in cells ${ }^{62}$ and directly related to an increase in ATP hydrolysis ${ }^{9}$. Not only has 2 -NBDG been used in ex vivo live tissues successfully ${ }^{70}$ but also, in future work, it could be used to track glucose uptake and therefore relative glycolytic rates ex vivo and in vivo during migration through highly relevant microenvironments to investigate dynamic metabolic plasticity.

\section{Visualizing $\mathrm{H}_{2} \mathrm{O}_{2}$ gradients}

Cells can respond to various environmental cues to regulate and drive migration. The "redox status" of cells, describing the relative levels of regulators of oxygen, can be determined by these cues and is regulated by the production of intermediates such as reactive oxygen species (ROS) like hydrogen peroxide $\left(\mathrm{H}_{2} \mathrm{O}_{2}\right)^{71} \cdot \mathrm{H}_{2} \mathrm{O}_{2}$ serves as an important second messenger since it is an oxidizing agent during cell metabolism ${ }^{72}$. Multiple probes have been developed incorporating a fluorescent protein with the $\mathrm{H}_{2} \mathrm{O}_{2}$-sensing protein OxyR to obtain real-time, live-cell tracking of $\mathrm{H}_{2} \mathrm{O}_{2}$ localization in the cell to gain insight on the redox state and $\mathrm{H}_{2} \mathrm{O}_{2}$ gradient ${ }^{72-74}$. The recently developed and most sensitive of these probes is HyPer 7 , which can detect very low concentrations of $\mathrm{H}_{2} \mathrm{O}_{2}$ while being $\mathrm{pH}$ stable $^{72}$. Using this probe, protrusion formation and cell polarization was shown to rely significantly on the $\mathrm{H}_{2} \mathrm{O}_{2}$ concentration at the leading edge of cells and the steepness of the $\mathrm{H}_{2} \mathrm{O}_{2}$ gradient from the protrusion to the cell body was found to directly correlate with the stability of the protrusion. This gradient, observed using a HyPer variant, has additionally been reported to change based on mechanical environmental cues, for instance confinement, to alter lamellipodia formation and induce migration toward available oxygen ${ }^{75}$. Though further work is required to understand exactly how this $\mathrm{H}_{2} \mathrm{O}_{2}$ gradient and signaling directs migration and cell polarization, the increased sensitivity of this probe, and others, has provided a unique avenue for further exploration.

While these probes correlate migratory events with real-time metabolic readouts, they also point to mechanisms by which cell migration is directly affected by intracellular bioenergetics. In the future, the use of these probes in vivo could aid in unveiling migratory mechanisms of cells experiencing altered biochemical and mechanical cues that are often too complex to replicate in vitro.

\section{Collective migration and leader/follower heterogeneities}

Metabolism in collective migration and 3D culture models

Recently, metabolic heterogeneities in collective cell populations have gained increased interest. Collective cell migration, in contrast to single cell migration, relies not only on cues from the microenvironment but also on signaling and interaction with surrounding cells. Cells migrating en masse can show differential responses to surrounding $\operatorname{cues}^{76}$ and are thought to minimize energetic costs compared to single cells, effectively preserving energy for cells to navigate more challenging environments ${ }^{9,77-79}$. One could speculate that collectively migrating cells utilize different strategies to achieve cell-cell communication and collective invasion, as cells may experience metabolic rewiring and/or swap positions due to leader cell energy depletion to efficiently invade ${ }^{31,80}$ (Figure 2). Glycolytic regulation of ATP/ADP ratios in cells has also been

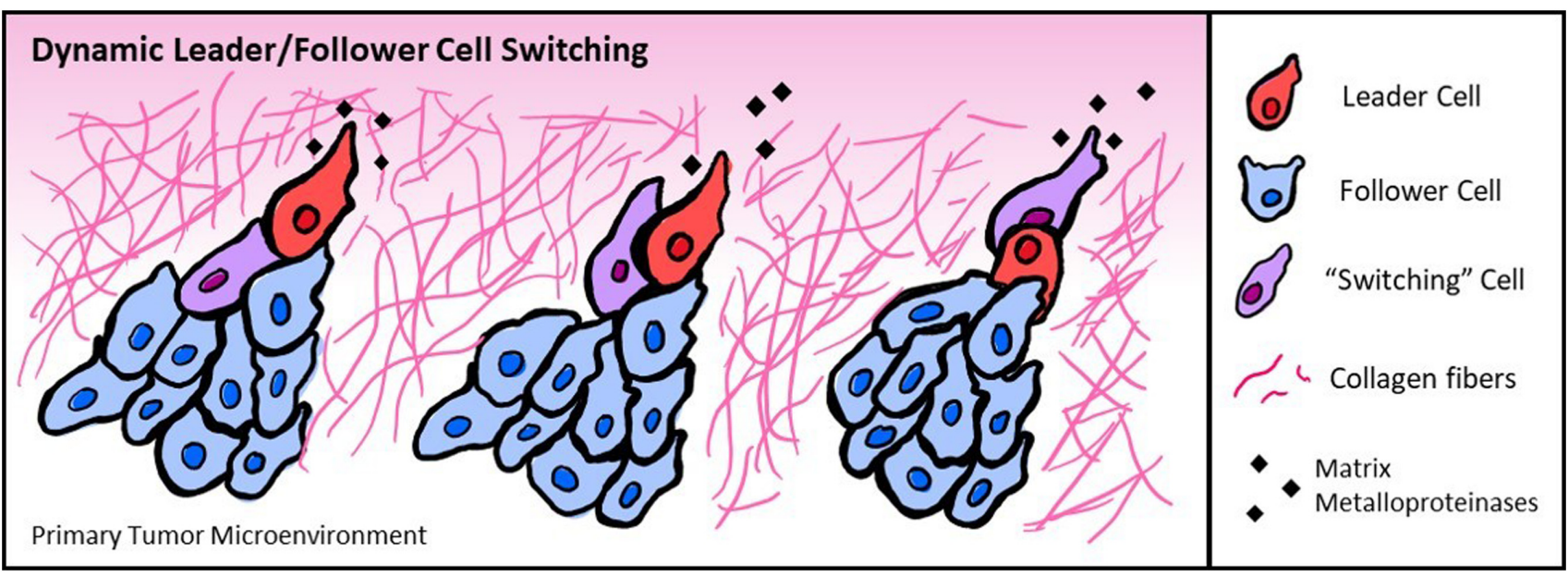

Figure 2. Dynamic leader/follower switching during collective migration allows energy-depleted leader cells to be replaced with new leader cells at collective cell front. Cues from the microenvironment such as collagen density may alter energy utilization and migratory behavior. Matrix metalloproteinases, potentially activated because of acidification of the surrounding microenvironment during glycolysis, can help to degrade the extracellular matrix. 
reported to play a key role in cytoskeletal remodeling, cell migration, and leader cell competitiveness during events like vessel sprouting ${ }^{81}$. Thus, ATP generation and trafficking in the cell is essential to a variety of collective processes.

Metabolic plasticity in collective migration may allow cells to meet dynamically changing energy needs within a heterogeneous microenvironment that presents cells with varying obstacles. For example, when cells encounter denser microenvironments and energy demands are increased, ATP has been shown to be generated through the OXPHOS pathway via mitochondrial trafficking to the leading edge of individually migrating cells, opposing the traditional Warburg theory ${ }^{8}$. In these high-density, energy-demanding environments, cells typically switch from single cell to collective migration ${ }^{78}$, suggesting that collective migration may provide some protection from energy depletion and migratory advantage. Similarly, increased substrate stiffness has been shown to result in higher collective cell migration speed, persistence, and area of multicellular protrusions ${ }^{82,83}$. Because stiffness gradients within the ECM can also affect the directionality and coordination of collective cell movements ${ }^{84,85}$, it is likely that varying stiffnesses result in an altered metabolic response in collective cells. As cell clusters may simultaneously experience heterogeneous stiffness and stress distributions due to the organization of the microenvironment ${ }^{85}$, determining how cells meet these localized energy demands and employ different energy production strategies is integral in probing collective cell behavior.

As increasing interest in collective cell energetics emerges, 3D culture models have gained attention as tools for investigating mechanisms of collective cell migration in relation to disease progression, especially in tumor metastasis ${ }^{86-92}$. Among the various collective migration models available, spheroids and organoids have been specifically used to investigate the relationship between collective cell migratory ability and environmental cues ${ }^{93-97}$. These highly relevant tools have been used in attempting to unveil potential mechanisms for how cell heterogeneity, migratory modes, and the microenvironment all contribute to a dynamically changing metabolic profile of migrating cells ${ }^{31,32,80,98-102}$.

Environmental cues like peroxide gradients or hypoxia can be formed in $3 \mathrm{D}$ culture models that can be used to specifically probe leader/follower dynamics in the context of the cellular redox state. When human apurinic/apyrimidinic endonuclease-1 (APE1), a key regulator of ROS production and redox state, was inhibited in breast cancer cells, collective migration was significantly inhibited, suggesting that ROS generation and regulation plays an important role not only during single cell migration but also in collective invasion and migration ${ }^{103}$. Given these data, it is possible that the redox status of individual cells during collective cell migration contributes to the metabolic differences between leader and follower cell populations and using HyPer and other peroxide probes may provide more information when used in a collective context. At high doses, $\mathrm{H}_{2} \mathrm{O}_{2}$ treatment has been shown to modulate junction proteins in collective cells and effectively inhibit migration in various cancer cell lines ${ }^{104-106}$. Additionally, hypoxia gradients have been shown to induce collective-to-amoeboid transition in cancer cells, in which single cells in collective masses are able to escape the leading edge and switch to an amoeboid migratory mode ${ }^{107}$. This suggests that even within collective masses, cells react on an individual level to changing hypoxic gradients and ROS modulation to more efficiently navigate their external environment. Future use of peroxide and ROS-related probes in models like spheroids or organoids should reveal how leader/ follower cells may rely on various oxygen levels to fill their roles during collective migration.

\section{Leader/follower dynamics}

Observing the metabolic plasticity of collectively migrating cells has led to a recent focus on the distinction between the independent roles of leader/follower cells. The formation of phenotypically unique leader cells from follower cells is reportedly dependent on dynamic collective stresses in follower cells that can in some instances pull leader cells into position $^{108}$. As energy utilization in this mechanism is still not fully understood, molecular probes and fluorescent labeling have been employed to determine how the differences between these two distinct cell groups are established and affected by metabolic requirements. For instance, cells expressing GFP-labeled keratin-14 in primary breast tumor organoids were found not only at the leading edge of collective cells to direct migration but also in follower positions that can engage in leader/follower switching events in response to both microenvironmental cues and intracellular energy needs ${ }^{31,109,110}$. Utilizing RFP-tagged and CycleTrak-labeled MDA-MB-231s, it has been shown that cells guided by environmental cues may compete for a dynamically changing leader cell position to minimize energetic costs during ECM invasion ${ }^{31,77}$. Thus, probing individual cell behavior with various fluorescent biomarkers has further clarified the metabolic determinants of different subpopulations during collective migration; moreover, these findings have suggested that the regulation of leader/follower cell metabolic profile by the surrounding microenvironment is critical to collective migration.

\section{Metabolic and phenotypic heterogeneities in leader/ follower cells}

Molecular probes are a powerful tool for dissecting the processes of collective migration, especially in the context of bioenergetics and cancer. Unlike Seahorse, which requires large cell

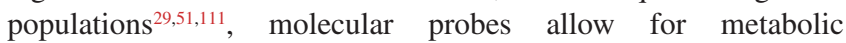
profiling of individual cells in collective migration, highlighting the spatial and temporal heterogeneities in leader/follower dynamics. The PercevalHR probe has been used to observe available energy in leader cells during collective cancer cell invasion in vitro through dense collagen, which is directly related to 
leader cell lifetime and leader/follower positions ${ }^{31}$. Using the 2-NBDG probe, it has been separately reported that leader cells exhibited higher glucose uptake than follower cells, suggesting increased glycolysis ${ }^{31}$, while another reported the preferential usage of OXPHOS by leader cells ${ }^{32}$. Though it is clear that collective cell populations maintain complex metabolic heterogeneity, how cells utilize different metabolic pathways during collective migration remains unclear. These real-time cell tracking techniques not only shed light on cell metabolism during migration but also, more importantly, point to the need for further investigation into leader versus follower cell behavior.

To understand the needs of individual leader and follower cells during migration, researchers have taken advantage of the ability to physically sort heterogeneous subpopulations based on their distinct phenotypic, genotypic, and metabolic profiles using tools such as photoactivation and spatiotemporal genomic and cellular analysis $(\mathrm{SaGA})^{31,112}$. These techniques employ the use of photoconvertible tags to identify and mark individual cells in collective populations that can then be sorted and expanded into discrete subpopulations. By creating separate populations characterized by mutations affecting invasive capability ${ }^{113}$, highly invasive leader cells were shown to rely on focal adhesion kinase-fibronectin signaling to promote invasion, while follower cells instead are recruited to leader cells via irregular VEGF-based vasculogenic signaling ${ }^{112}$. Further definition of unique subpopulations can also be determined using single-cell sequencing, probing the metabolic heterogeneities in bulk expression profiles to link metabolic gene expression during in vitro cell migration with in vivo metastasis ${ }^{14-117}$. By specifically studying these populations, a fuller understanding of their interactions and roles in collective cell migration can be gained, particularly in the context of invasive diseases like cancer.

Recently, it has been shown that cells can be sorted without the use of specific probes or photoactivation but rather based on autofluorescence of the metabolic intermediates $\mathrm{NAD}(\mathrm{P}) \mathrm{H}$ and $\mathrm{FAD}^{66,118-120}$. High levels of $\mathrm{NAD}(\mathrm{P}) \mathrm{H}$ autofluorescence may serve as a useful biomarker for increased OXPHOS ${ }^{119}$, though it may be difficult to fully parse the contributions of NADH and NADPH to metabolism and whether these changes specifically point to mitochondrial respiration or glycolysis ${ }^{57}$. Nonetheless, autofluorescence has provided a probe-free avenue for exploring the metabolic preference in cells that could lend to easier characterization of migratory metabolism in the future.

As studies continue to investigate the metabolic activity of leader/follower cell populations, conflicting reports have emerged regarding the utilization of glycolysis and/or mitochondrial respiration during collective migration. In cancer, leader cells have been shown in some instances to rely on glycolysis, as demonstrated by increased ATP/ADP ratios and increased glucose uptake ${ }^{31}$, while others show a dependence on OXPHOS $^{32}$, as shown by increased sensitivity of leader cells to mitochondrial-targeting treatment. During glycolysis, the tumor microenvironment is acidified owing to the increase in lactate production by cells ${ }^{52,121}$, which has been linked to the activation of matrix metalloproteinases ${ }^{122,123}$, important mediators of matrix degradation. This evidence supports the idea that leader cells rely more heavily on glycolysis, potentially to aid in matrix remodeling for migration, and further highlights how leader/follower phenotypic heterogeneity may be sustained or partially altered by the microenvironment. As future studies continue to reveal distinct leader/follower profiles, these opposing reports may be resolved with further investigation into how leader/follower dynamics and complex microenvironmental cues regulate migratory metabolism.

\section{Conclusions}

In very recent work, cell migration research has focused on understanding the role of metabolic heterogeneities in cell migration. Studies have narrowed from visualizing intracellular energetics in single cell and collective groups of cells to sorting cells into specific populations and characterizing the phenotypic and genotypic differences in these subpopulations. This is made feasible through the use of photoactivation and cell sorting, with characterization made simple using molecular probes that allow visual and quantitative comparison of metabolic processes in migrating cells. However, tools and techniques for monitoring and quantifying energy production and consumption in real time in vivo are still lacking and will be essential in understanding cellular energy status of migrating cells in highly complex and relevant environments. Additionally, in primary or patient-derived cell lines where cells are more fragile and last shorter time periods in vitro, molecular probes requiring several passages for transduction and even selection can be technically difficult to utilize. Therefore, the development of a less-invasive tool to visualize and quantify intracellular energy status in these cells will be particularly useful in future cell migration work.

Recent research has revealed that individual cell populations hold key heterogeneities that independently contribute to the migration of collective cell groups as a whole, with metabolic intermediates playing an essential role in determining the function and role of these cells. Whether these heterogeneities are inherent in the cell or dependent on surrounding conditions has yet to be fully explored and is of key interest in future work. As it is still unclear which metabolic pathways are prioritized by specific cell subpopulations, further investigation into these questions is essential to fully understand the mechanisms of both single and collective cell migration, especially in the context of a complicated disease-developing environment. 
1. Vander Heiden MG, Cantley LC, Thompson CB: Understanding the Warburg effect: The metabolic requirements of cell proliferation. Science. 2009; 324(5930): 1029-33.

PubMled Abstract | Publisher Full Text | Free Full Text

2. Chen $\mathrm{Y}$, Nielsen J: Energy metabolism controls phenotypes by protein efficiency and allocation. Proc Natl Acad Sci U S A. 2019; 116(35): 17592-7. PubMed Abstract | Publisher Full Text | Free Full Text | Faculty Opinions Recommendation

3. $\mathrm{Li}$ Y, Yao L, Mori Y, et al:: On the energy efficiency of cell migration in diverse physical environments. Proc Natl Acad Sci U S A. 2019; 116(48): 23894-900.

PubMed Abstract | Publisher Full Text | Free Full Text |

Faculty Opinions Recommendation

4. Iommarini L, Ghelli A, Gasparre G, et al:: Mitochondrial metabolism and energy sensing in tumor progression. Biochim Biophys Acta Bioenerg. 2017; 1858(8): 582-90.

PubMed Abstract | Publisher Full Text

5. Pfeiffer T, Schuster S, Bonhoeffer S: Cooperation and competition in the evolution of ATP-producing pathways. Science. 2001; 292(5516): 504-7. PubMed Abstract | Publisher Full Text

6. Paudel BB, Quaranta V: Metabolic plasticity meets gene regulation. Proc Nat/ Acad Sci U S A. 2019; 116(9): 3370-2.

PubMed Abstract | Publisher Full Text | Free Full Text

7. Jia $\mathrm{D}$, Lu M, Jung $\mathrm{KH}$, et al.: Elucidating cancer metabolic plasticity by coupling gene regulation with metabolic pathways. Proc Natl Acad Sci U S A. 2019; 116(9): 3909-18.

PubMed Abstract | Publisher Full Text | Free Full Text

8. Cunniff B, McKenzie AJ, Heintz NH, et al.: AMPK activity regulates trafficking of mitochondria to the leading edge during cell migration and matrix invasion. Mol Biol Cell. 2016; 27(17): 2662-74.

PubMed Abstract | Publisher Full Text | Free Full Text

9. Zanotelli MR, Goldblatt ZE, Miller JP, et al.: Regulation of ATP utilization during metastatic cell migration by collagen architecture. Mol Biol Cell. 2018; 29(1): $1-9$.

PubMed Abstract | Publisher Full Text | Free Full Text

10. Ridley AJ, Paterson HF, Johnston CL, et al:: The small GTP-binding protein rac regulates growth factor-induced membrane ruffling. Cell. 1992; 70(3): 401-10. PubMed Abstract | Publisher Full Text

11. Wolf $\mathrm{K}$, Mazo I, Leung $\mathrm{H}$, et al.: Compensation mechanism in tumor cell migration: Mesenchymal-amoeboid transition after blocking of pericellular proteolysis. J Cell Biol. 2003; 160(2): 267-77.

PubMed Abstract | Publisher Full Text | Free Full Text | Faculty Opinions Recommendation

12. Bergert M, Chandradoss SD, Desai RA, et al.: Cell mechanics control rapid transitions between blebs and lamellipodia during migration. Proc Natl Acad Sci U S A. 2012; 109(36): 14434-9.

PubMed Abstract | Publisher Full Text | Free Full Text |

Faculty Opinions Recommendation

13. Zhu J, Mogilner A: Comparison of cell migration mechanical strategies in three-dimensional matrices: A computational study. Interface Focus. 2016; 6(5): 20160040.

PubMed Abstract | Publisher Full Text | Free Full Text

14. Sahai E, Marshall CJ: Differing modes of tumour cell invasion have distinct requirements for Rho/ROCK signalling and extracellular proteolysis. Nat Cell Biol. 2003; 5(8): 711-9.

PubMed Abstract | Publisher Full Text

15. Wyckoff JB, Pinner SE, Gschmeissner S, et al.: ROCK- and myosindependent matrix deformation enables protease-independent tumor-cell invasion in vivo. Current Biology. 2006; 16(15): 1515-23. PubMed Abstract | Publisher Full Text | Faculty Opinions Recommendation

16. Holle AW, Devi NGK, et al:: Cancer Cells Invade Confined Microchannels via a Self-Directed Mesenchymal-to-Amoeboid Transition. Nano Lett. 2019; 19(4): 2280-90.

PubMed Abstract | Publisher Full Text | Free Full Text | Faculty Opinions Recommendation

17. Jones BC, Kelley LC, Loskutov YV, et al.: Dual Targeting of Mesenchymal and Amoeboid Motility Hinders Metastatic Behavior. Mol Cancer Res. 2017; 15(6): $670-82$.

PubMed Abstract | Publisher Full Text | Free Full Text

18. Huang B, Lu M, Jolly MK, et al.: The three-way switch operation of Rac1/RhoA GTPase-based circuit controlling amoeboid-hybrid-mesenchymal transition. Sci Rep. 2014; 4: 6449.

PubMed Abstract | Publisher Full Text | Free Full Text

19. Talkenberger K, Cavalcanti-Adam EA, Voss-Böhme A, et al:: Amoeboidmesenchymal migration plasticity promotes invasion only in complex heterogeneous microenvironments. Sci Rep. 2017; 7(1): 9237.

PubMed Abstract | Publisher Full Text | Free Full Text

20. Friedl $\mathrm{P}$, Alexander $\mathrm{S}$ : Cancer invasion and the microenvironment: Plasticity and reciprocity. Cell. 2011; 147(5): 992-1009.

PubMed Abstract | Publisher Full Text

21. Mosier JA, Rahman-Zaman A, Zanotelli MR, et al.: Extent of Cell Confinement in Microtracks Affects Speed and Results in Differential Matrix Strains. Biophys J. 2019; 117(9): 1692-701.

PubMed Abstract | Publisher Full Text | Free Full Text

22. Wu H, Ying M, Hu X: Lactic acidosis switches cancer cells from aerobic glycolysis back to dominant oxidative phosphorylation. Oncotarget. 2016; 7(26): 40621-9.

PubMed Abstract | Publisher Full Text | Free Full Text

23. Molinie N, Gautreau A: Directional Collective Migration in Wound Healing Assays. Methods Mol Biol. 2018; 1749: 11-9.

PubMed Abstract | Publisher Full Text

24. Nardini JT, Chapnick DA, Liu X, et al:: Modeling keratinocyte wound healing dynamics: Cell-cell adhesion promotes sustained collective migration. $J$ Theor Biol. 2016; 400: 103-17.

PubMed Abstract | Publisher Full Text | Free Full Text

25. Scarpa E, Mayor R: Collective cell migration in development. J Cell Biol. 2016; 212(2): 143-55

PubMed Abstract | Publisher Full Text | Free Full Text

26. Park JA, Atia L, Mitchel JA, et al.: Collective migration and cell jamming in asthma, cancer and development. J Cell Sci. 2016; 129(18): 3375-83. PubMed Abstract | Publisher Full Text | Free Full Text

27. Kajstura J, Korohoda W: Significance of energy metabolism pathways for stimulation of DNA synthesis by cell migration and serum. Eur J Cell Biol. 1983; 31(1): 9-14. PubMed Abstract

28. Liu Z, Jia $X$, Duan $Y$, et al.: Excess glucose induces hypoxia-inducible factor-1 $\alpha$ in pancreatic cancer cells and stimulates glucose metabolism and cell migration. Cancer Biol Ther. 2013; 14(5): 428-35. PubMed Abstract | Publisher Full Text | Free Full Text

29. Guak H, Al Habyan S, Ma EH, et al.: Glycolytic metabolism is essential fo CCR7 oligomerization and dendritic cell migration. Nat Commun. 2018; 9(1): 2463.

PubMed Abstract | Publisher Full Text | Free Full Text Faculty Opinions Recommendation

30. Zanotelli MR, Rahman-Zaman A, VanderBurgh JA, et al:: Energetic costs regulated by cell mechanics and confinement are predictive of migration path during decision-making. Nat Commun. 2019; 10(1): 4185. PubMed Abstract | Publisher Full Text | Free Full Text | Faculty Opinions Recommendation

31. Zhang J, Goliwas KF, Wang W, et al:: Energetic regulation of coordinated leader-follower dynamics during collective invasion of breast cancer cells. Proc Natl Acad Sci U S A. 2019; 116(16): 7867-72. PubMed Abstract | Publisher Full Text | Free Full Text Faculty Opinions Recommendation

32. Commander R, Wei C, Sharma A, et al:: Subpopulation targeting of pyruvate dehydrogenase and GLUT1 decouples metabolic heterogeneity during collective cancer cell invasion. Nat Commun. 2020; 11(1): 1533. PubMed Abstract | Publisher Full Text | Free Full Text | Faculty Opinions Recommendation

33. Kelbauskas L, Glenn $\mathrm{H}$, Anderson $\mathrm{C}$, et al:: A platform for high-throughput bioenergy production phenotype characterization in single cells. Sci Rep. 2017; 7: 45399 .

PubMed Abstract | Publisher Full Text | Free Full Text

34. Divakaruni AS, Rogers GW, Murphy AN: Measuring Mitochondrial Function in Permeabilized Cells Using the Seahorse XF Analyzer or a Clark-Type Oxygen Electrode. Curr Protoc Toxicol. 2014; 60: 25.2.1-16.

PubMed Abstract | Publisher Full Text

35. Yépez VA, Kremer LS, luso A, et al:: OCR-Stats: Robust estimation and statistical testing of mitochondrial respiration activities using Seahorse XF Analyzer. PLoS One. 2018; 13(7): e0199938.

PubMed Abstract | Publisher Full Text | Free Full Text

36. TeSlaa T, Teitell MA: Techniques to monitor glycolysis. Meth Enzymol. 2014; 542 91-114.

PubMed Abstract | Publisher Full Text | Free Full Text

37. Liu J, Li HW, Wu Y: A highly selective and sensitive fluorescent probe for lactate dehydrogenase based on ultrabright adenosine monophosphate capped gold nanoclusters. RSC Adv. 2017; 7: 13438-43. Publisher Full Text

38. Arce-Molina R, Cortés-Molina F, Sandoval PY, et al:: A highly responsive pyruvate sensor reveals pathway-regulatory role of the mitochondrial 
pyruvate carrier MPC. eLife. 2020; 9: e53917.

PubMed Abstract | Publisher Full Text | Free Full Text |

Faculty Opinions Recommendation

39. Zhang G, Sun Y, He X, et al:: Red-Emitting Mitochondrial Probe with Ultrahigh Signal-to-Noise Ratio Enables High-Fidelity Fluorescent Images in Two-Photon Microscopy. Anal Chem. 2015; 87(24): 12088-95. PubMed Abstract | Publisher Full Text

40. Bursac $\mathrm{P}$, Lenormand $\mathrm{G}$, Fabry $\mathrm{B}$, et al.: Cytoskeletal remodelling and slow dynamics in the living cell. Nat Mater. 2005; 4(7): 557-61. PubMed Abstract | Publisher Full Text

41. Korn ED, Carlier MF, Pantaloni D: Actin polymerization and ATP hydrolysis. Science. 1987; 238(4827): 638-44. PubMed Abstract | Publisher Full Text

42. C Li A, Leung CT, Peterson-Yantorno K, et al:: Cytoskeletal dependence of adenosine triphosphate release by human trabecular meshwork cells. Invest Ophthalmol Vis Sci. 2011; 52(11): 7996-8005.

PubMed Abstract | Publisher Full Text | Free Full Text |

Faculty Opinions Recommendation

43. Balaban RS: Regulation of oxidative phosphorylation in the mammalian cell. Am J Physiol. 1990; 258(3 Pt1): C377-89. PubMed Abstract | Publisher Full Text

44. Tantama M, Martínez-François JR, Mongeon R, et al:: Imaging energy status in live cells with a fluorescent biosensor of the intracellular ATP-to-ADP ratio. Nat Commun. 2013; 4: 2550.

PubMed Abstract | Publisher Full Text | Free Full Text

45. Berg J, Hung YP, Yellen G: A genetically encoded fluorescent reporter of ATP:ADP ratio. Nat Methods. 2009; 6(2): 161-6.

PubMed Abstract | Publisher Full Text | Free Full Text |

Faculty Opinions Recommendation

46. Nguyen PTM, Ishiwata-Kimata Y, Kimata Y: Monitoring ADP/ATP ratio in yeast cells using the fluorescent-protein reporter PercevalHR. Biosci Biotechnol Biochem. 2019; 83(5): 824-8.

PubMed Abstract | Publisher Full Text

47. Calì T, Ottolini D, Soriano ME, et al.: A new split-GFP-based probe reveals DJ-1 translocation into the mitochondrial matrix to sustain ATP synthesis upon nutrient deprivation. Hum Mol Genet. 2015; 24(4): 1045-60. PubMed Abstract | Publisher Full Text

48. Georgiadou E, Haythorne E, Dickerson MT, et al:: The pore-forming subunit MCU of the mitochondrial $\mathrm{Ca}^{2+}$ uniporter is required for normal glucose-stimulated insulin secretion in vitro and in vivo in mice. Diabetologia. 2020; 63(7): 1368-1381.

PubMed Abstract | Publisher Full Text | Free Full Text

49. Haythorne E, Rohm M, van de Bunt M, et al.: Diabetes causes marked inhibition of mitochondrial metabolism in pancreatic $\beta$-cells. Nat Commun. 2019; 10(1): 2474.

PubMed Abstract | Publisher Full Text | Free Full Text

50. Cedric B, Alessandra P, Dave G, et al:: The dynamic interplay between ATP/ ADP levels and autophagy sustain neuronal migration in vivo. bioRxiv. 2020. Publisher Full Text

51. Schuler MH, Lewandowska A, Di Caprio G, et al:: Miro1-mediated mitochondrial positioning shapes intracellular energy gradients required for cell migration. Mol Biol Cell. 2017; 28(16): 2159-2169. PubMed Abstract | Publisher Full Text | Free Full Text

52. Warburg O, Wind F, Negelein E: The metabolism of tumors in the body. J Gen Physiol. 1927; 8(6): 519-30.

PubMed Abstract | Publisher Full Text | Free Full Text

53. Beckner ME, Stracke ML, Liotta LA, et al:: Glycolysis as primary energy source in tumor cell chemotaxis. J Natl Cancer Inst. 1990; 82(23): 1836-40. PubMed Abstract | Publisher Full Text

54. Fu H, Zhou H, Yu X, et al:: Wounding triggers MIRO-1 dependent mitochondrial fragmentation that accelerates epidermal wound closure through oxidative signaling. Nat Commun. 2020; 11(1): 1050

PubMed Abstract | Publisher Full Text | Free Full Text | Faculty Opinions Recommendation

55. Stein LR, Imai SI: The dynamic regulation of NAD metabolism in mitochondria Trends Endocrinol Metab. 2012; 23(9): 420-8.

PubMed Abstract | Publisher Full Text | Free Full Text

56. Hung YP, Albeck JG, Tantama M, et al:: Imaging cytosolic NADH-NAD(+) redox state with a genetically encoded fluorescent biosensor. Cell Metab. 2011; 14(4): 545-54.

PubMed Abstract | Publisher Full Text | Free Full Text

57. Hung YP, Yellen G: Live-cell imaging of cytosolic NADH-NAD+ redox state using a genetically encoded fluorescent biosensor. Methods Mol Biol. 2014; 1071: 83-95.

PubMed Abstract | Publisher Full Text | Free Full Text

58. Tejwani V, Schmitt FJ, Wilkening S, et al.: Investigation of the NADH/NAD+ ratio in Ralstonia eutropha using the fluorescence reporter protein Peredox. Biochim Biophys Acta Bioenerg. 2017; 1858(1): 86-94.

PubMed Abstract | Publisher Full Text

59. Bhat SA, Iqbal IK, Kumar A: Imaging the NADH:NAD+ Homeostasis for Understanding the Metabolic Response of Mycobacterium to Physiologically
Relevant Stresses. Front Cell Infect Microbiol. 2016; 6: 145 PubMed Abstract | Publisher Full Text | Free Full Text

60. Díaz-García CM, Mongeon R, Lahmann C, et al:: Neuronal Stimulation Triggers Neuronal Glycolysis and Not Lactate Uptake. Cell Metab. 2017; 26(2): 361-374.e4

PubMed Abstract | Publisher Full Text | Free Full Text | Faculty Opinions Recommendation

61. Rabinovich S, Silberman A, Adler L, et al.: The mitochondrial carrier Citrin plays a role in regulating cellular energy during carcinogenesis. Oncogene. 2020; 39(1): 164-75.

PubMed Abstract | Publisher Full Text | Faculty Opinions Recommendation

62. Bhattacharya D, Azambuja AP, Simoes-Costa M: Metabolic Reprogramming Promotes Neural Crest Migration via Yap/Tead Signaling. Dev Cell. 2020; 53(2): 199-211.e6.

PubMed Abstract | Publisher Full Text | Free Full Text |

Faculty Opinions Recommendation

63. Padhi A, Thomson AH, Perry JB, et al.: Bioenergetics underlying singlecell migration on aligned nanofiber scaffolds. Am J Physiol Cell Physiol. 2020; 318(3):

PubMed Abstract | Publisher Full Text | Free Full Text |

Faculty Opinions Recommendation

64. Costanza B, Rademaker G, Tiamiou A, et al:: Transforming growth factor betainduced, an extracellular matrix interacting protein, enhances glycolysis and promotes pancreatic cancer cell migration. Int J Cancer. 2019; 145(6): 1570-1584.

PubMed Abstract | Publisher Full Text

65. Prasad CP, Södergren K, Andersson T: Reduced production and uptake of lactate are essential for the ability of WNT5A signaling to inhibit breast cancer cell migration and invasion. Oncotarget. 2017; 8(42): 71471-71488. PubMed Abstract | Publisher Full Text | Free Full Text

66. Gaude E, Schmidt C, Gammage PA, et al.: NADH Shuttling Couples Cytosolic Reductive Carboxylation of Glutamine with Glycolysis in Cells with Mitochondrial Dysfunction. Mol Cell. 2018; 69(4): 581-593.e7. PubMed Abstract | Publisher Full Text | Free Full Text

67. Liu QP, Luo Q, Deng B, et al:: Stiffer Matrix Accelerates Migration of Hepatocellular Carcinoma Cells through Enhanced Aerobic Glycolysis Via the MAPK-YAP Signaling. Cancers (Basel). 2020; 12(2): 490 PubMed Abstract | Publisher Full Text | Free Full Text | Faculty Opinions Recommendation

68. Im D-K, Cheong H, Lee JS, et al.: Protein kinase CK2-dependent aerobic glycolysis-induced lactate dehydrogenase $A$ enhances the migration and glycolysis-induced lactate dehydrogenase A enhancion of cancer cells. Sci Rep. 2019; 9 (1): 5337.
invasion PubMed Abstract | Publisher Full Text | Free Full Text

69. Zou C, Wang Y, Shen Z: 2-NBDG as a fluorescent indicator for direct glucose uptake measurement. J Biochem Biophys Methods. 2005; 64(3): 207-15. PubMed Abstract | Publisher Full Text

70. Dunn AF, Catterton MA, Dixon DD, et al.: Spatially Resolved Measurement of Dynamic Glucose Uptake in Live Ex Vivo Tissues. bioRxiv. 2020; 2020.04.17.047068. Publisher Full Text

71. Smith KA, Waypa GB, Schumacker PT: Redox signaling during hypoxia in mammalian cells. Redox Biol. 2017; 13: 228-34. PubMed Abstract | Publisher Full Text | Free Full Text

72. Pak VV, Ezeriņa D, Lyublinskaya OG, et al:: Ultrasensitive Genetically Encoded Indicator for Hydrogen Peroxide Identifies Roles for the Oxidant in Cell Migration and Mitochondrial Function. Cell Metab. 2020; 31(3): 642-653.e6. PubMed Abstract | Publisher Full Text | Free Full Text |

Faculty Opinions Recommendation

73. Bilan DS, Belousov VV: HyPer Family Probes: State of the Art. Antioxid Redox Signal. 2016; 24(13): 731-51. PubMed Abstract | Publisher Full Text

74. Belousov VV, Fradkov AF, Lukyanov KA, et al:: Genetically encoded fluorescent indicator for intracellular hydrogen peroxide. Nat Meth. 2006; 3(4): 281-6. PubMed Abstract | Publisher Full Text | Faculty Opinions Recommendation

75. Deygas M, Gadet R, Gillet $G$, et al.: Redox regulation of EGFR steers migration of hypoxic mammary cells towards oxygen. Nat Commun. 2018; 9(1): 4545. PubMed Abstract | Publisher Full Text | Free Full Text | Faculty Opinions Recommendation

76. Isozaki Y, Sakai K, Kohiro K, et al:: The Rho-guanine nucleotide exchange factor Solo decelerates collective cell migration by modulating the Rho-ROCK pathway and keratin networks. Mol Biol Cell. 2020; 31(8): 741-52. PubMed Abstract | Publisher Full Text | Free Full Text | Faculty Opinions Recommendation

77. Liu L, Duclos G, Sun B, et al.: Minimization of thermodynamic costs in cancer cell invasion. Proc Natl Acad Sci U S A. 2013; 110(5): 1686-91. PubMed Abstract | Publisher Full Text | Free Full Text 
78. Haeger A, Krause M, Wolf $\mathrm{K}$, et al.: Cell jamming: Collective invasion of mesenchymal tumor cells imposed by tissue confinement. Biochim Biophys Acta. 2014; 1840(8): 2386-95.

PubMed Abstract | Publisher Full Text

79. Pally D, Pramanik D, Bhat R: An Interplay Between Reaction-Diffusion and Cell-Matrix Adhesion Regulates Multiscale Invasion in Early Breast Carcinomatosis. Front Physiol. 2019; 10: 790 . PubMed Abstract | Publisher Full Text | Free Full Text | Faculty Opinions Recommendation

80. Roy M, Finley SD: Metabolic reprogramming dynamics in tumor spheroids: Insights from a multicellular, multiscale model. PLoS Comput Biol. 2019; 15(6): e1007053.

PubMed Abstract | Publisher Full Text | Free Full Text |

Faculty Opinions Recommendation

81. Cruys B, Wong BW, Kuchnio A, et al:: Glycolytic regulation of cell rearrangement in angiogenesis. Nat Commun. 2016; 7: 12240.

PubMed Abstract | Publisher Full Text | Free Full Text

82. Carriga EH, Franze K, Charras G, et al:: Tissue stiffening coordinates morphogenesis by triggering collective cell migration in vivo. Nature. 2018; 554(7693): 523-7.

PubMed Abstract | Publisher Full Text | Free Full Text |

Faculty Opinions Recommendation

83. Balcioglu HE, Balasubramaniam L, Stirbat TV, et al.: A subtle relationship between substrate stiffness and collective migration of cell clusters. Soft Matter. 2020; 16(7): 1825-39.

PubMed Abstract | Publisher Full Text

84. Malik AA, Gerlee P: Mathematical modelling of cell migration: Stiffness dependent jump rates result in durotaxis. J Math Biol. 2019; 78(7): 2289-315. PubMed Abstract | Publisher Full Text | Free Full Text

85. Garcia-Gonzalez D, Muñoz-Barrutia A: Computational insights into the influence of substrate stiffness on collective cell migration. Extreme Mech Lett. 2020; 40: 100928.

Publisher Full Text | Faculty Opinions Recommendation

86. Kim YH, Choi YW, Lee J, et al:: Senescent tumor cells lead the collective invasion in thyroid cancer. Nat Commun. 2017; 8: 15208. PubMed Abstract | Publisher Full Text | Free Full Text

87. Huang W, Navarro-Serer B, Jeong YJ, et al.: Pattern of Invasion in Human Pancreatic Cancer Organoids Is Associated with Loss of SMAD4 and Clinical Outcome. Cancer Res. 2020; 80(13): 2804-17.

PubMed Abstract | Publisher Full Text | Free Full Text | Faculty Opinions Recommendation

88. Florian $\mathrm{S}$, Iwamoto $\mathrm{Y}$, Coughlin $\mathrm{M}$, et al: : A human organoid system that selforganizes to recapitulate growth and differentiation of a benign mammary tumor. Proc Natl Acad Sci U S A. 2019; 116(23): 11444-53. PubMed Abstract | Publisher Full Text | Free Full Text

89. Yoon $\mathrm{HH}$, Bhang $\mathrm{SH}$, Shin JY, et al:: Enhanced cartilage formation via threedimensional cell engineering of human adipose-derived stem cells. Tissue Eng Part A. 2012; 18(19-20): 1949-56.

PubMed Abstract | Publisher Full Text | Free Full Text

90. Bhang SH, Cho SW, La WG, et al:: Angiogenesis in ischemic tissue produced by spheroid grafting of human adipose-derived stromal cells. Biomaterials. 2011; 32(11): 2734-47.

PubMed Abstract | Publisher Full Text

91. Kim J, Zheng Y, Alobaidi AA, et al.: Geometric Dependence of 3D Collective Cancer Invasion. Biophys J. 2020; 118(5): 1177-82. PubMed Abstract | Publisher Full Text | Free Full Text | Faculty Opinions Recommendation

92. Du W, Hong S, Scapin G, et al.: Directed Collective Cell Migration Using Three-Dimensional Bioprinted Micropatterns on Thermoresponsive Surfaces for Myotube Formation. ACS Biomater Sci Eng. 2019; 5(8): 3935-43. PubMed Abstract | Publisher Full Text | Free Full Text

93. Plou J, Juste-Lanas $\mathrm{Y}$, Olivares $\mathrm{V}$, et al:: From individual to collective 3D cancer

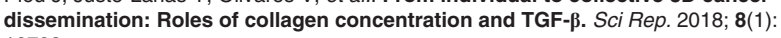
12723.

PubMed Abstract | Publisher Full Text | Free Full Text

94. McKenzie AJ, Hicks SR, Svec KV, et al.: The mechanical microenvironment regulates ovarian cancer cell morphology, migration, and spheroid disaggregation. Sci Rep. 2018; 8(1): 7228

PubMed Abstract | Publisher Full Text | Free Full Text

95. Beaune G, Blanch-Mercader C, Douezan S, et al:: Spontaneous migration of cellular aggregates from giant keratocytes to running spheroids. Proc Natl Acad SciU S A. 2018; 115(51): 12926-31.

PubMed Abstract | Publisher Full Text | Free Full Text

96. Dubbin K, Robertson C, Hinckley A, et al.: Macromolecular gelatin properties affect fibrin microarchitecture and tumor spheroid behavior in fibrin-gelatin gels. Biomaterials. 2020; 250: 120035.

PubMed Abstract | Publisher Full Tex

97. Labernadie A, Kato T, Brugués A, et al.: A mechanically active heterotypic
$\mathrm{E}$-cadherin/ $\mathrm{N}$-cadherin adhesion enables fibroblasts to drive cancer cell invasion. Nat Cell Biol. 2017; 19(3): 224-37. PubMed Abstract | Publisher Full Text | Free Full Text Faculty Opinions Recommendation

98. Russell S, Wojtkowiak J, Neilson A, et al.: Metabolic Profiling of healthy and cancerous tissues in 2D and 3D. Sci Rep. 2017; 7(1): 15285. PubMed Abstract | Publisher Full Text | Free Full Text

99. Walenta S, Doetsch J, Mueller-Klieser W, et al:: Metabolic imaging in multicellular spheroids of oncogene-transfected fibroblasts. J Histochem Cytochem. 2000; 48(4): 509-22.

PubMed Abstract | Publisher Full Text

100. Venkatasubramanian R, Henson MA, Forbes NS: Incorporating energy metabolism into a growth model of multicellular tumor spheroids. J Theor Biol. 2006; 242(2): 440-53.

PubMed Abstract | Publisher Full Text

101. Valli A, Morotti M, Zois CE, et al:: Adaptation to HIF1 $\alpha$ Deletion in Hypoxic Cancer Cells by Upregulation of GLUT14 and Creatine Metabolism. Mol Cancer Res. 2019; 17(7): 1531-44.

Res. 2019; 17(7): 1531-44.
PubMed Abstract | Publisher Full Text | Faculty Opinions Recommendation

102. Rodríguez-Enríquez S, Gallardo-Pérez JC, Avilés-Salas A, et al.: Energy metabolism transition in multi-cellular human tumor spheroids. J Cell Physiol. 2008; 216(1): 189-97.

PubMed Abstract | Publisher Full Text

103. Guerreiro PS, Corvacho E, Costa JG, et al.: The APE1 redox inhibitor E3330 reduces collective cell migration of human breast cancer cells and decreases chemoinvasion and colony formation when combined with docetaxel. Chem Biol Drug Des. 2017; 90(4): 561-71. PubMed Abstract | Publisher Full Text

104. Luanpitpong S, Talbott SJ, Rojanasakul Y, et al:: Regulation of lung cancer cell migration and invasion by reactive oxygen species and caveolin-1. $J$ Biol Chem. 2010; 285(50): 38832-40. PubMed Abstract | Publisher Full Text | Free Full Text

105. Ma L, Zhu WZ, Liu TT, et al: $\mathrm{H2O}$ inhibits proliferation and mediates suppression of migration via DLC1/RhoA signaling in cancer cells. Asian Pac J Cancer Prev. 2015; 16(4): 1637-42. PubMed Abstract | Publisher Full Text

106. Rao R: Oxidative stress-induced disruption of epithelial and endothelial tight junctions. Front Biosci. 2008; 13: 7210-26. PubMed Abstract | Publisher Full Text | Free Full Text

107. Lehmann S, Te Boekhorst V, Odenthal J, et al:: Hypoxia Induces a HIF-1Dependent Transition from Collective-to-Amoeboid Dissemination in Epithelial Cancer Cells. Curr Biol. 2017; 27(3): 392-400. PubMed Abstract | Publisher Full Text

108. Vishwakarma M, Di Russo J, Probst D, et al:: Mechanical interactions among followers determine the emergence of leaders in migrating epithelial cell collectives. Nat Commun. 2018; 9(1): 3469 PubMed Abstract | Publisher Full Text | Free Full Text | Faculty Opinions Recommendation

109. Gao XL, Wu JS, Cao MX, et al:: Cytokeratin-14 contributes to collective invasion of salivary adenoid cystic carcinoma. PLoS One. 2017; 12(2): e0171341. PubMed Abstract | Publisher Full Text | Free Full Text

110. H Hwang PY, Brenot A, King AC, et al.: Randomly Distributed K14+ Breast Tumor Cells Polarize to the Leading Edge and Guide Collective Migration in Response to Chemical and Mechanical Environmental Cues. Cancer Res. 2019; 79(8): 1899-912.

PubMed Abstract | Publisher Full Text | Free Full Text |

Faculty Opinions Recommendation

111. Thejer BM, Adhikary PP, Kaur A, et al:: PGRMC1 phosphorylation affects cell shape, motility, glycolysis, mitochondrial form and function, and tumor growth. BMC Mol Cell Biol. 2020; 21(1): 24. PubMed Abstract | Publisher Full Text | Free Full Text

112. Konen J, Summerbell E, Dwivedi B, et al.: Image-guided genomics of phenotypically heterogeneous populations reveals vascular signalling during symbiotic collective cancer invasion. Nat Commun. 2017; 8: 15078. PubMed Abstract | Publisher Full Text | Free Full Text

113. Zoeller EL, Pedro B, Konen J, et al.: Genetic heterogeneity within collective invasion packs drives leader and follower cell phenotypes. J Cell Sci. 2019; 132(19): jcs231514.

PubMed Abstract | Publisher Full Text | Free Full Text

Faculty Opinions Recommendation

114. Ariss MM, Islam ABMMK, Critcher M, et al:: Single cell RNA-sequencing identifies a metabolic aspect of apoptosis in Rbf mutant. Nat Commun. 2018; 9(1): 5024 . PubMed Abstract | Publisher Full Text | Free Full Text

115. Damiani C, Maspero D, Di Filippo M, et al:: Integration of single-cell RNA-seq data into population models to characterize cancer metabolism. PLOS Comput Biol. 2019; 15(2): e1006733.

PubMed Abstract | Publisher Full Text | Free Full Text 
116. Saurty-Seerunghen MS, Bellenger L, El-Habr EA, et al:: Capture at the single cell level of metabolic modules distinguishing aggressive and indolent glioblastoma cells. Acta Neuropathol Commun. 2019; 7(1): 155. PubMed Abstract | Publisher Full Text | Free Full Text

117. Xiao Z, Dai Z, Locasale JW: Metabolic landscape of the tumor microenvironment at single cell resolution. Nat Commun. 2019; 10(1): 3763. PubMed Abstract | Publisher Full Text | Free Full Text

118. Shah AT, Cannon TM, Higginbotham JN, et al:: Autofluorescence flow sorting of breast cancer cell metabolism. J Biophotonics. 2017; 10(8): 1026-33. PubMed Abstract | Publisher Full Text | Free Full Text

119. Bonuccelli G, de Francesco EM, de Boer R, et al:: NADH autofluorescence, a new metabolic biomarker for cancer stem cells: Identification of Vitamin C and CAPE as natural products targeting "stemness". Oncotarget. 2017; 8(13): 20667-78.

PubMed Abstract | Publisher Full Text | Free Full Text
120 for sortion Res Ther and characterizin

PubMed Abstract | Publisher Full Text | Free Full Text |

Faculty Opinions Recommendation

121. Bailey KM, Wojtkowiak JW, Hashim Al, et al.: Targeting the metabolic microenvironment of tumors. Adv Pharmacol. 2012; 65: 63-107. PubMed Abstract | Publisher Full Text | Free Full Text

122. Romero-Garcia S, Moreno-Altamirano MMB, Prado-Garcia $\mathrm{H}$, et al.: Lactate Contribution to the Tumor Microenvironment: Mechanisms, Effects on Immune Cells and Therapeutic Relevance. Front Immunol. 2016; 7: 52. PubMed Abstract | Publisher Full Text | Free Full Text

123. Webb BA, Chimenti M, Jacobson MP, et al:: Dysregulated pH: A perfect storm for cancer progression. Nat Rev Cancer. 2011; 11(9): 671-7. PubMed Abstract | Publisher Full Text 